\title{
Paenibacillus motobuensis sp. nov., isolated from a composting machine utilizing soil from Motobu-town, Okinawa, Japan
}

Correspondence
Ken-ichiro lida
iida@bact.med.kyushu-u.ac.jp

\author{
Ken-ichiro lida, ${ }^{1}$ Yasuichi Ueda, ${ }^{2}$ Yoshiaki Kawamura, ${ }^{3}$ Takayuki Ezaki, ${ }^{3}$ \\ Akemi Takade, ${ }^{1}$ Shin-ichi Yoshida ${ }^{1}$ and Kazunobu Amako ${ }^{1}$ \\ ${ }^{1}$ Department of Bacteriology, Faculty of Medical Sciences, Kyushu University, 3-1-1 Maidashi, \\ Higashi-ku, Fukuoka-city, Fukuoka, 812-8582, Japan \\ ${ }^{2}$ Motobu Noge Hospital, 880-1 Ohama, Motobu-cho, Kunigami-gun, Okinawa, 905-0212, Japan \\ ${ }^{3}$ Department of Microbiology, Regeneration and Advanced Medical Science, Gifu University \\ Graduate School of Medicine, 1-1 Yanagido, Gifu-city, Gifu, 501-1194, Japan
}

\begin{abstract}
A novel bacterial strain, $\mathrm{MC}^{\top} 0^{\top}$, was isolated from a compost sample produced in a composting machine utilizing soil from Motobu-town, Okinawa, Japan. The isolate was Gram-negative, but produced endospores. These conflicting characters prompted a taxonomic study of the isolate. The isolate was examined using a combination of phenotypic characterization, cellular fatty acid analysis, DNA base composition determination and 16S rRNA gene sequence analysis. Phylogenetic analysis, based on 16S rRNA gene sequence comparisons, placed strain $\mathrm{MC} 10^{\top}$ within the genus Paenibacillus. As in other Paenibacillus species, the isolate contained anteiso- $\mathrm{C}_{15: 0}$ as the major fatty acid and the DNA G+C content was $47.0 \mathrm{~mol} \%$. However, $16 \mathrm{~S}$ rRNA gene sequence similarity values of less than $95.6 \%$ were found between this isolate and all members of the genus Paenibacillus. Based upon these results, strain MC10 $0^{\top}\left(=\right.$ GTC $1835^{\top}=\mathrm{JCM} 12774^{\top}=$ CCUG $\left.50090^{\top}\right)$ should be designated as the type strain of a novel species within the genus Paenibacillus, Paenibacillus motobuensis sp. nov.
\end{abstract}

Until the early 1990s, all aerobic, endospore-forming bacteria were classified as the genus Bacillus. In recent years, the genus Bacillus has been separated into several distinct genera, such as Amphibacillus (Niimura et al., 1990), Alicyclobacillus (Wisotzkey et al., 1992), Paenibacillus (Ash et al., 1993), Aneurinibacillus and Brevibacillus (Shida et al., 1996), Halobacillus (Spring et al., 1996), Virgibacillus (Heyndrickx et al., 1998), Gracilibacillus and Salibacillus (Wainø et al., 1999), Anoxybacillus (Pikuta et al., 2000), Coprobacillus (Kageyama \& Benno, 2000), Filobacillus (Schlesner et al., 2001), Geobacillus (Nazina et al., 2001), Ureibacillus (Fortina et al., 2001), Jeotgalibacillus and Marinibacillus (Yoon et al., 2001). The genus Paenibacillus was created by the separation of the so-called group 3 bacilli (Ash et al., 1993); the new genus included 11 species. Since

Published online ahead of print on 29 April 2005 as DOI 10.1099/ ijs.0.63636-0.

The GenBank/EMBL/DDBJ accession number for the $16 \mathrm{~S}$ rRNA gene sequence of strain $M C 10^{\top}$ is $A Y 741810$.

A table of $16 \mathrm{~S}$ rRNA gene sequence similarities between $\mathrm{MC} 10^{\top}$ and several Paenibacillus species, a transmission electron micrograph showing flagella and an expanded phylogenetic tree are available as supplementary material in IJSEM Online. this reclassification, additional transfers to the genus Paenibacillus and proposals for novel strains to be designated as Paenibacillus species have increased. Members of the genus Paenibacillus are aerobic, or facultatively anaerobic, organisms that produce ellipsoidal endospores in swollen sporangia and the cell wall shows structures typical of Gram-positive bacteria, but sometimes stains negatively. The DNA G + C content ranges from 40 to $54 \mathrm{~mol} \%$ and anteiso- $\mathrm{C}_{15: 0}$ is the major cellular fatty acid.

Recently, the problems of garbage produced from everyday living have become serious issues, especially in urban areas. Incineration has been used in the past as a common method of waste disposal. However, the production of toxic substances, especially dioxin, during incineration has become a major problem. Alternative methods for waste disposal are needed in order to avoid environmental pollution.

A heat-producing reaction was observed in a mixture of garbage and soil at Motobu-town, Okinawa, Japan. Using this phenomenon, a composting machine was developed by one of us (Y.U.). This machine comprises an airtight container that can withstand three times atmospheric pressure and a motor used for mixing the garbage inside the vessel. After an hour of operation, the temperature in the 
machine increases to over $130^{\circ} \mathrm{C}$. By using this machine, garbage was broken down and turned into a soil-like substance. The mechanisms by which such high temperatures are produced are not clear and studies to analyse this phenomenon with biological and biochemical techniques have been performed. During a study to identify bacteria in the samples from this machine, a Gram-negative, but sporeforming, strain was isolated. The strain was named $\mathrm{MC} 0^{\mathrm{T}}$ and was considered to represent a Paenibacillus species based on the phylogenetic analysis of the 16S rRNA gene sequence. Based on the 16S rRNA gene sequence, phenotypic characteristics, DNA base composition and cellular fatty acid composition analysis, we propose that strain $\mathrm{MC}^{\mathrm{T}}{ }^{\mathrm{T}}$ is classified as the type strain of Paenibacillus motobuensis sp. nov.

Strain $\mathrm{MC} 10^{\mathrm{T}}$ was isolated from a compost sample collected from a composting machine. Serially-diluted compost suspensions were inoculated onto Luria-Bertani agar ( $\mathrm{pH}$ 6) (Sambrook et al., 1989). After colony isolation, the strain was cultivated at $37^{\circ} \mathrm{C}$ for $48 \mathrm{~h}$ on trypticase soy agar (TSA; Difco) for chromosomal DNA extraction and on BUGM medium (Biolog) for the Biolog substrate utilization test. Tests for the utilization of substrates as the sole carbon source were performed with Biolog GP microplates (Biolog) containing 95 different carbon compounds, according to the manufacturer's instructions. Catalase and oxidase activity assays, the nitrate reduction test and the VogesProskauer test were carried out as described previously (Smibert \& Krieg, 1994). Cell morphology was observed using light microscopy and transmission electron microscopy (TEM). Flagellum type was determined by TEM. Bacteria grown statically in trypticase soy broth (TSB; Difco) for $24 \mathrm{~h}$ were shadowed with chromium and examined with a JEM2000EX (JEOL) electron microscope. An ultrastructural study was carried out by using colonies and cells grown on TSA at $37^{\circ} \mathrm{C}$ for $48 \mathrm{~h}$. The freezesubstitution fixation technique was used for thin sectioning of samples for TEM (Amako et al., 1983; Amako \& Takade, 1985).

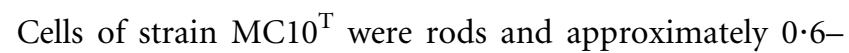
$1 \cdot 0 \times 1 \cdot 0-3 \cdot 0 \mu \mathrm{m}$ in size. The strain was facultatively anaerobic and motile by means of peritrichous flagella (Supplementary Fig. S1 in IJSEM Online). The isolate produced ellipsoidal endospores in swollen sporangia in the terminal region of the cell (Fig. 1a). Colonies of the isolate grown on TSA were flat, smooth and opaque white. Growth was found to be optimal at $37^{\circ} \mathrm{C}$, with a range from 25 to $55^{\circ} \mathrm{C}$. Although the optimal growth temperature for the majority of the members of the genus Paenibacillus has been reported to be $28-30^{\circ} \mathrm{C}$ (Shida et al., 1997a), several novel Paenibacillus species have been described with temperature optima at around $37-40{ }^{\circ} \mathrm{C}$ (Shida et al., 1997b; Yoon et al., 1998; Tcherpakov et al., 1999; Meehan et al., 2001; Velázquez et al., 2004). Strain $\mathrm{MC}^{\mathrm{T}}{ }^{\mathrm{T}}$ was found to be Gram-negative, but no apparent outer membrane structure was observed in the cell wall (Fig. 1b) and the cell wall
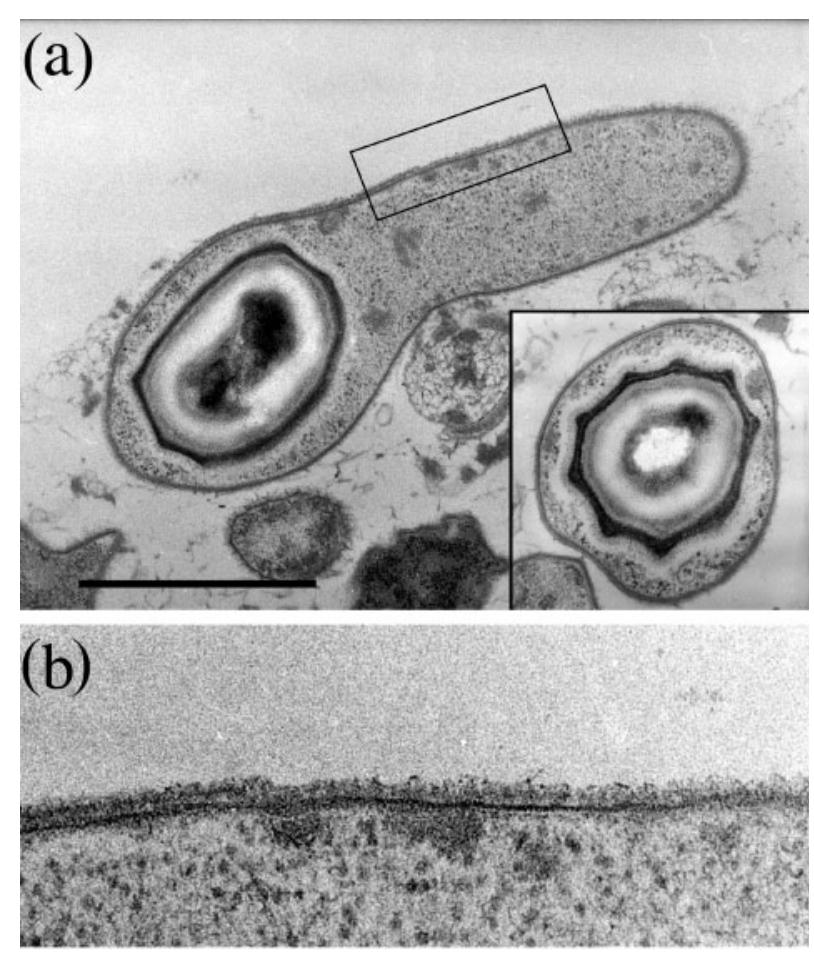

Fig. 1. Ultrastructure of strain $M C 10^{\top}$. (a) TEM of an ultrathin section showing an endospore in a swollen sporangium. Crosssectionally cut spores are shown in box. (b) Magnified part of (a) (in rectangle). Bar, $1 \mu \mathrm{m}$.

structure was more like that of the Gram-positive bacteria. Some members of the genus Paenibacillus, such as Paenibacillus glucanolyticus and Paenibacillus macquariensis, have been known to give a Gram-negative reaction (Marshall \& Ohye, 1966; Dasman et al., 2002). The endospores had nine projections from the outer spore coat (Fig. 1a). Strain $\mathrm{MC} 10^{\mathrm{T}}$ showed catalase and oxidase activity and reduced nitrate to nitrite. The utilization of 95 substrates as the sole carbon source was tested using the Biolog GP plate and the results are noted in the description. Physiological characteristics, including selected data from the carbon utilization test for strain $\mathrm{MC}^{\mathrm{T}}{ }^{\mathrm{T}}$, were compared with those of its closest phylogenetic relatives, Paenibacillus azoreducens, P. cineris, P. cookii, P. favisporus and P. chibensis (Table 1).

Chromosomal DNA was extracted and purified as described by Ezaki et al. (1994). G + C content was determined by the HPLC method (Ezaki et al., 1990) using a packed column (Wakosil 5C18; Wako). The G+C content was calculated using Escherichia coli $\mathrm{K}-12$ strain DNA as a standard $(51 \cdot 12 \mathrm{~mol} \% \mathrm{G}+\mathrm{C})$. The $16 \mathrm{~S}$ rRNA gene sequence corresponding to positions $8-1485$ in the E. coli numbering system (Brosius et al., 1978) was amplified by PCR and sequenced according to Ezaki et al. (1994). The PCR product was purified with a Microcon Spincolumn (Millipore). Sequencing of the purified PCR product was performed using an ABI PRISM BigDye Terminator cycle sequencing 
Table 1. Characteristics of $P$. motobuensis $\mathrm{sp}$. nov. and closely related Paenibacillus species

Strains: 1, Paenibacillus motobuensis sp. nov. $\mathrm{MC}^{\mathrm{T}}{ }^{\mathrm{T}} ; 2$, P. azoreducens DSM $13822^{\mathrm{T}}$ (data from Meehan et al., 2001); 3, P. cineris LMG $18439^{\mathrm{T}}$ (Logan et al., 2004); 4, P. cookii LMG $18419^{\mathrm{T}}$ (Logan et al., 2004); 5, P. favisporus $\mathrm{GMP}^{\mathrm{T}}{ }^{\mathrm{T}}$ (Velázquez et al., 2004); 6, P. chibensis NRRL B-142 ${ }^{\mathrm{T}}$ (Shida et al., 1997b). +, Positive; - , negative; W, weak; V, variable; ND, not determined.

\begin{tabular}{|lcccccc|}
\hline Characteristic & $\mathbf{1}$ & $\mathbf{2}$ & $\mathbf{3}$ & $\mathbf{4}$ & $\mathbf{5}$ & $\mathbf{6}$ \\
\hline Growth at $50{ }^{\circ} \mathrm{C}$ & + & + & + & + & - & + \\
Optimum growth temp. $\left({ }^{\circ} \mathrm{C}\right)$ & 37 & 37 & 30 & 30 & 37 & 37 \\
Oxidase & + & - & + & + & + & - \\
Nitrate reduction & + & - & $\mathrm{ND}$ & $\mathrm{ND}$ & + & + \\
Voges-Proskauer test & - & - & $\mathrm{V}$ & + & + & - \\
Utilization of: & & & & & & \\
N-Acetylglucosamine & - & + & + & - & $\mathrm{ND}$ & $\mathrm{ND}$ \\
D-Arabinose & - & + & $\mathrm{V}$ & - & $\mathrm{ND}$ & - \\
L-Fucose & - & - & - & + & $\mathrm{ND}$ & $\mathrm{ND}$ \\
Glycerol & + & + & - & + & $\mathrm{ND}$ & - \\
Glycogen & - & + & $\mathrm{V}$ & + & $\mathrm{ND}$ & $\mathrm{ND}$ \\
myo-Inositol & - & - & + & - & $\mathrm{ND}$ & $\mathrm{ND}$ \\
$\quad$ Mannitol & - & + & + & - & + & + \\
$\quad$ D-Melezitose & - & - & + & + & $\mathrm{ND}$ & $\mathrm{ND}$ \\
Sorbitol & - & - & $\mathrm{V}$ & - & $\mathrm{ND}$ & - \\
Growth in NaCl at 5\% & $\mathrm{W}$ & - & - & + & $\mathrm{W}$ & - \\
G + C content $(\mathrm{mol} \%)$ & 47 & 47 & 48 & 52 & 53 & 53 \\
\hline
\end{tabular}

ready reaction kit (Applied Biosystems) as recommended by the manufacturer. The purified sequencing reaction mixtures were electrophoresed automatically (model 3100; Applied Biosystems). The $16 \mathrm{~S}$ rRNA gene sequence of strain

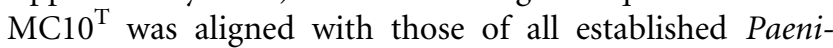
bacillus species and some other taxa using CLUSTAL $\mathrm{W}$ version 1.5 (Thompson et al., 1994). Other reference sequences were obtained from the DDBJ database. $16 \mathrm{~S}$ rRNA gene sequence similarity values were calculated using the CLUSTAL W package. A phylogenetic tree was constructed using the neighbour-joining method (Saitou \& Nei, 1987). A bootstrap analysis (Felsenstein, 1985) with 1000 replications was performed with the CLUSTAL $\mathrm{W}$ package to evaluate the topology of the phylogenetic tree. The Paenibacillusspecific primer PAEN515F and universal primer 1377R were applied to isolate $\mathrm{MC}^{\mathrm{T}} 0^{\mathrm{T}}$ for Paenibacillus-specific PCR according to the method of Shida et al. (1996, 1997a).

The DNA G $+\mathrm{C}$ content of strain $\mathrm{MC} 10^{\mathrm{T}}$ was $47 \cdot 0 \mathrm{~mol} \%$. The phylogenetic position of the strain, based on the almostcomplete 16S rRNA gene sequence of Paenibacillus species, including strain $\mathrm{MC}^{\mathrm{T}} 0^{\mathrm{T}}$, shown in Fig. 2, was constructed from evolutionary distances (Kimura, 1980) calculated by the neighbour-joining method (Saitou \& Nei, 1987). The 15 strains with the highest binary similarity values of $16 \mathrm{~S}$ rRNA sequences are presented in Supplementary Table S1 in IJSEM Online. The levels of 16S rRNA gene sequence similarity between strain $\mathrm{MC}^{\mathrm{T}}{ }^{\mathrm{T}}$ and Paenibacillus species ranged from 95.6\% (Paenibacillus azoreducens, DSM $13822^{\mathrm{T}}$, GenBank accession no. AJ272249) to $90 \cdot 2 \%$ (Paenibacillus alginolyticus, DSM $5050^{\mathrm{T}}$, accession no. D78465). The phylogenetic tree (Fig. 2) constructed from the 16S rRNA gene sequence data shows that strain $\mathrm{MC}^{\mathrm{T}}{ }^{\mathrm{T}}$ appeared within the genus Paenibacillus and occupied a distinct phylogenetic position within the genus (an expanded phylogenetic tree is available as Supplementary Fig. S2 in IJSEM Online). Species found to be closely related to strain $\mathrm{MC}^{\mathrm{T}}{ }^{\mathrm{T}}$ were $P$. azoreducens, $P$. chibensis, $P$. cineris, $P$. cookii and $P$. favisporus. The definition of a bacterial species suggests that strains with approximately $70 \%$ or greater DNA-DNA relatedness are members of the same species (Wayne et al., 1987). According to the available data (Stackebrandt \& Goebel, 1994), if the $16 \mathrm{~S}$ rRNA gene sequence similarities are less than $97 \cdot 0 \%$, the total chromosomal DNA extracted from two bacterial strains will not reassociate by more than $60 \%$, regardless of the hybridization method used. Keswani \& Whitman (2001) suggested a threshold value of $98.6 \%$ similarity for taxa where the rRNA gene sequences possess ultrameric properties and Drancourt et al. (2000) used $99 \%$ for species identification. Our isolate, $\mathrm{MC}^{\mathrm{T}}{ }^{\mathrm{T}}$, showed less than $95 \cdot 6 \%$ sequence similarity values among all members of the genus Paenibacillus. A PCR fragment $(0 \cdot 8 \mathrm{~kb})$ could be amplified from the DNA of $\mathrm{MC}^{\mathrm{T}} \mathrm{T}^{\mathrm{T}}$ using the primer combination of the genus-specific primer PAEN515F and universal primer 1377R (Shida et al., 1997a).

Analysis of cellular fatty acids was performed at the National Collections of Industrial and Marine Bacteria Japan Ltd. Briefly, biomass for cellular fatty acid analysis was prepared from a $24 \mathrm{~h}$ culture grown on a TSA plate at $30^{\circ} \mathrm{C}$. Fatty acid methyl esters were prepared according to the manufacturer's instructions for analysis using the MIDI Microbial Identification System (Hewlett Packard). The resultant esters were separated using a gas chromatograph (model 6890; Hewlett Packard).

The major fatty acids found in isolate $\mathrm{MC}^{\mathrm{T}} 0^{\mathrm{T}}$ are shown in Table 2 and are compared with values available for phylogenetically related Paenibacillus strains. Anteiso-branched $\mathrm{C}_{15: 0}$, the major fatty acid in the genus Paenibacillus (Shida et al., 1997a), was also the major fatty acid component of strain $\mathrm{MC}^{\mathrm{T}} 0^{\mathrm{T}}$, comprising $39 \cdot 8 \%$ of the total. Other major $(>10 \%)$ fatty acids were straight-chain $\mathrm{C}_{16: 0}$ and isobranched $\mathrm{C}_{15: 0}, \mathrm{C}_{16: 0}$ and $\mathrm{C}_{17: 0}$. The fatty acid profile of strain $\mathrm{MC} 10^{\mathrm{T}}$ was similar to those of selected members of the genus Paenibacillus, but there were differences in the proportions of some fatty acids.

In conclusion, according to the combined morphological, physiological, chemotaxonomic and phylogenetic data discussed here, it is evident that strain $\mathrm{MC} 10^{\mathrm{T}}$ belongs to the genus Paenibacillus. The genetic distinctiveness inferred from the phylogenetic study validates the proposal of this strain as representing a novel species, Paenibacillus motobuensis sp. nov. 


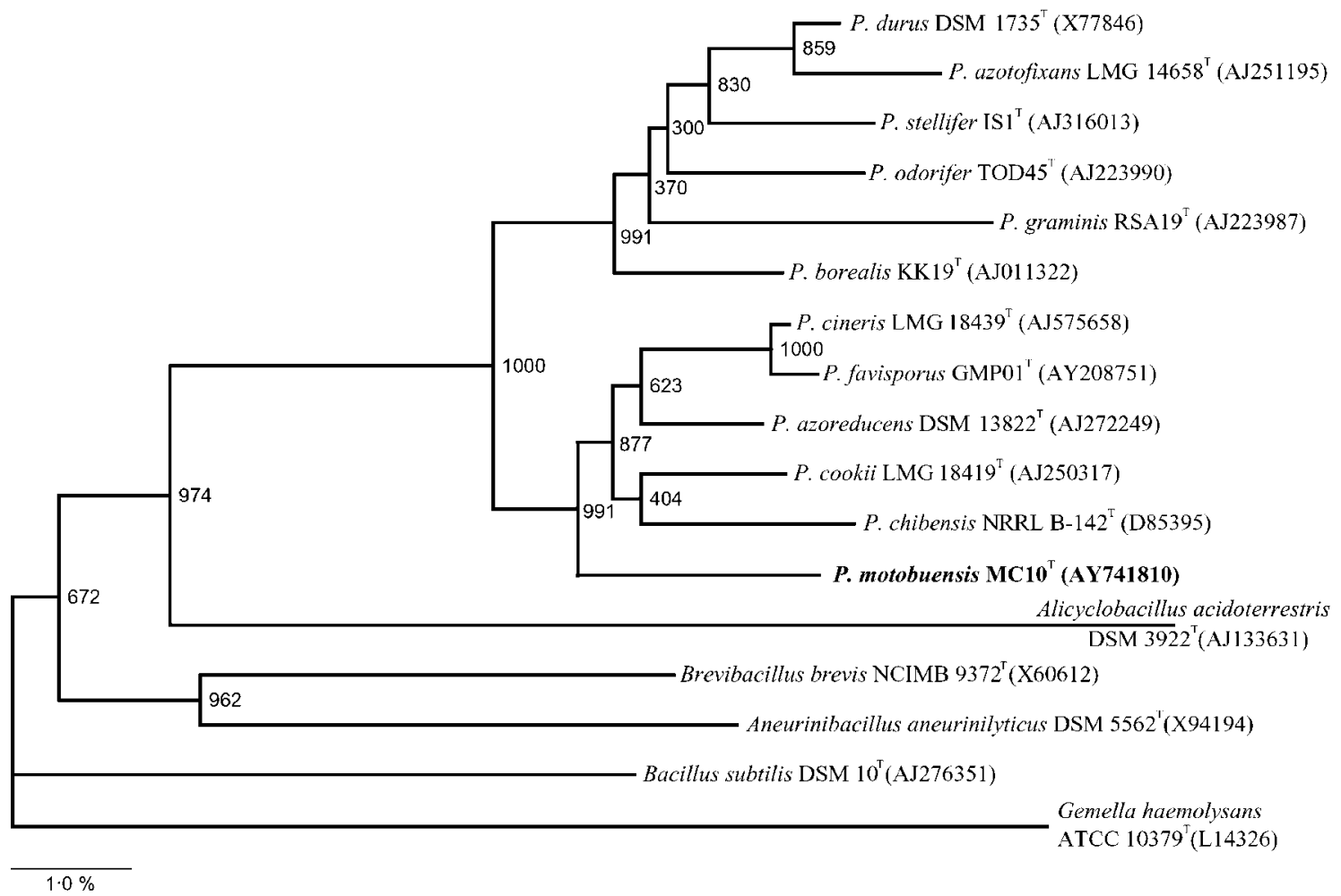

Fig. 2. Phylogenetic tree showing the position of $P$. motobuensis $M C 10^{\top}$ in relation to several Paenibacillus species and some rod-shaped, endospore-forming bacteria based on 16S rRNA gene sequences. Gemella haemolysans ATCC 10379 (L14326) was used as the outgroup. Numbers at branching points refer to bootstrap values (1000 resampling). Bar, $1 \cdot 0 \%$ sequence divergence.

Table 2. Cellular fatty acid profiles of some Paenibacillus species and strain $\mathrm{MC} 10^{\top}$

Species: 1, Paenibacillus motobuensis sp. nov. $\mathrm{MC}^{\mathrm{T}}$; 2, P. azoreducens DSM $13822^{\mathrm{T}}$ (data from Meehan et al., 2001); 3, $P$. cineris LMG $18439^{\mathrm{T}}$ (Logan et al., 2004); 4, P. cookii LMG $18419^{\mathrm{T}}$ (Logan et al., 2004); 5, P. favisporus GMP01 ${ }^{\mathrm{T}}$ (Velázquez et al., 2004); 6, P. chibensis NRRL B-142 $2^{\mathrm{T}}$ (Shida et al., 1997b). ND, Not determined. Values are percentages of total fatty acids.

\begin{tabular}{|lrccccr|}
\hline Fatty acid & $\mathbf{1}$ & $\mathbf{2}$ & $\mathbf{3}$ & $\mathbf{4}$ & $\mathbf{5}$ & $\mathbf{6}$ \\
\hline Straight-chain: & & & & & & \\
$\mathrm{C}_{14: 0}$ & $1 \cdot 1$ & $3 \cdot 5$ & $\mathrm{ND}$ & $\mathrm{ND}$ & $\mathrm{ND}$ & $0 \cdot 3$ \\
$\mathrm{C}_{15: 0}$ & $1 \cdot 7$ & $0 \cdot 1$ & $\mathrm{ND}$ & $\mathrm{ND}$ & $3 \cdot 6$ & $0 \cdot 6$ \\
$\mathrm{C}_{16: 0}$ & $10 \cdot 3$ & $22 \cdot 1$ & $18 \cdot 0$ & $11 \cdot 0$ & $8 \cdot 7$ & $5 \cdot 3$ \\
Iso-branched: & & & & & & \\
$\mathrm{C}_{14: 0}$ & $1 \cdot 5$ & $0 \cdot 8$ & $\mathrm{ND}$ & $\mathrm{ND}$ & $0 \cdot 9$ & $0 \cdot 8$ \\
$\mathrm{C}_{15: 0}$ & $14 \cdot 7$ & $5 \cdot 9$ & $6 \cdot 0$ & $6 \cdot 5$ & $6 \cdot 5$ & $4 \cdot 0$ \\
$\mathrm{C}_{16: 0}$ & $10 \cdot 5$ & $8 \cdot 6$ & $9 \cdot 0$ & $13 \cdot 0$ & $11 \cdot 1$ & $12 \cdot 2$ \\
$\mathrm{C}_{17: 0}$ & $10 \cdot 1$ & $5 \cdot 6$ & $\mathrm{ND}$ & $\mathrm{ND}$ & $\mathrm{ND}$ & $3 \cdot 2$ \\
Anteiso-branched: & & & & & & \\
$\mathrm{C}_{13: 0}$ & $0 \cdot 2$ & $5 \cdot 6$ & $\mathrm{ND}$ & $\mathrm{ND}$ & $3 \cdot 3$ & $3 \cdot 2$ \\
$\mathrm{C}_{15: 0}$ & $39 \cdot 8$ & $33 \cdot 9$ & $46 \cdot 0$ & $36 \cdot 0$ & $48 \cdot 8$ & $57 \cdot 8$ \\
$\mathrm{C}_{17: 0}$ & $9 \cdot 3$ & $19 \cdot 8$ & $10 \cdot 0$ & $20 \cdot 0$ & $15 \cdot 0$ & $14 \cdot 3$ \\
\hline
\end{tabular}

\section{Description of Paenibacillus motobuensis sp. nov.}

Paenibacillus motobuensis (mo.to.bu.en'sis. N.L. masc. adj. motobuensis pertaining to Motobu in Okinawa, Japan, where the type strain was isolated).

Rod-shaped cells with a length of approx. $1 \cdot 0-3 \cdot 0 \mu \mathrm{m}$ and a width of $0 \cdot 6-1 \cdot 0 \mu \mathrm{m}$. Cells are motile by means of peritrichous flagella and produce terminally located ellipsoidal spores. Colonies are circular, flat, smooth and opaque white. Facultatively anaerobic. Cells stain Gram-negative; however, the cell wall structure is that of Gram-positive bacteria. Positive catalase and oxidase reactions. Negative VogesProskauer reaction. Nitrate is reduced to nitrite. The temperature range for growth is $20-55^{\circ} \mathrm{C}$, with the optimum being $37^{\circ} \mathrm{C}$. The $\mathrm{pH}$ range for growth is $6 \cdot 0-8 \cdot 0$, the optimum being $\mathrm{pH} 8 \cdot 0$. Growth occurs in the presence of $5 \% \mathrm{NaCl}$ but is inhibited by $10 \% \mathrm{NaCl}$. Anteiso-branched $\mathrm{C}_{15: 0}(39 \cdot 8 \%)$ represents the major cellular fatty acid. Utilizes $\alpha$-cyclodextrin, $\beta$-cyclodextrin, dextrin, amygdalin, arbutin, cellobiose, D-fructose, D-galactose, gentiobiose, Dgluconic acid, $\alpha$-D-glucose, maltose, maltotriose, D-mannose, methyl $\alpha$-D-galactoside, palatinose, D-psicose, salicin, sucrose, D-trehalose, turanose, D-xylose, $\alpha$-ketovaleric acid, methyl 
pyruvate, 2,3-butanediol, glycerol and adenosine (utilization data were obtained with Biolog GP microplates). The DNA G + C content of the type strain is $47 \cdot 0 \mathrm{~mol} \%$ (determined by HPLC).

The type strain $\mathrm{MC} 10^{\mathrm{T}}\left(=\mathrm{GTC} 1835^{\mathrm{T}}=\mathrm{JCM} 12774^{\mathrm{T}}=\right.$ CCUG $50090^{\mathrm{T}}$ ), was isolated from a composting machine containing soil from Motobu, Okinawa, Japan. The $16 \mathrm{~S}$ rRNA gene sequence of this strain is deposited at DDBJ under accession number AY741810.

\section{References}

Amako, K. \& Takade, A. (1985). The fine structure of Bacillus subtilis revealed by the rapid-freezing and substitution fixation method. J Electron Microsc 34, 13-17.

Amako, K., Murata, K. \& Umeda, A. (1983). Structure of the envelope of Escherichia coli observed by the rapid-freezing and substitution fixation method. Microbiol Immunol 27, 95-99.

Ash, C., Priest, F. G. \& Collins, M. D. (1993). Molecular identification of rRNA group 3 bacilli (Ash, Farrow, Wallbanks and Collins) using a PCR probe test. Proposal for the creation of a new genus Paenibacillus. Antonie van Leeuwenhoek 64, 253-260.

Brosius, J., Palmer, M. L., Kennedy, P. J. \& Noller, H. F. (1978). Complete nucleotide sequence of a $16 \mathrm{~S}$ ribosomal RNA gene from Escherichia coli. Proc Natl Acad Sci U S A 75, 4801-4805.

Dasman, Kajiyama, S., Kawasaki, H., Yagi, M., Seki, T., Fukasaki, E. \& Kobayashi, A. (2002). Paenibacillus glycanilyticus sp. nov., a novel species that degrades heteropolysaccharide produced by the cyanobacterium Nostoc commune. Int J Syst Evol Microbiol 52, 1669-1674.

Drancourt, M., Bollet, C., Carlioz, A., Martelin, R., Gayral, J. P. \& Raoult, D. (2000). 16S ribosomal DNA sequence analysis of a large collection of environmental and clinical unidentifiable bacterial isolates. J Clin Microbiol 38, 3623-3630.

Ezaki, T., Saidi, S. M., Liu, S. L., Hashimoto, Y., Yamamoto, H. \& Yabuuchi, E. (1990). Rapid procedure to determine the DNA base composition from small amounts of Gram-positive bacteria. FEMS Microbiol Lett 67, 127-130.

Ezaki, T., Li, N., Hashimoto, Y., Miura, H. \& Yamamoto, H. (1994). $16 \mathrm{~S}$ ribosomal DNA sequence of anaerobic cocci and proposal of Ruminococcus hansenii comb. nov. and Ruminococcus productus comb. nov. Int J Syst Bacteriol 44, 130-136.

Felsenstein, J. (1985). Confidence limits on phylogenies: an approach using the bootstrap. Evolution 39, 783-791.

Fortina, M. G., Pukall, R., Schumann, P., Mora, D., Parini, C., Manachini, P. L. \& Stackebrandt, E. (2001). Ureibacillus gen. nov., a new genus to accommodate Bacillus thermosphaericus (Andersson et al. 1995), emendation of Ureibacillus thermosphaericus and description of Ureibacillus terrenus sp. nov. Int J Syst Evol Microbiol 51, 447-455.

Heyndrickx, M., Lebbe, L., Kersters, K., De Vos, P., Forsyth, G. \& Logan, N. A. (1998). Virgibacillus: a new genus to accommodate Bacillus pantothenticus (Proom and Knight 1950). Emended description of Virgibacillus pantothenticus. Int J Syst Bacteriol 48, 99-106.

Kageyama, A. \& Benno, Y. (2000). Coprobacillus catenaformis gen. nov., sp. nov., a new genus and species isolated from human feces. Microbiol Immunol 44, 23-28.

Keswani, J. \& Whitman, W. B. (2001). Relationship of $16 \mathrm{~S}$ rRNA sequence similarity to DNA hybridization in prokaryotes. Int J Syst Evol Microbiol 51, 667-678.
Kimura, M. (1980). A simple method for estimating evolutionary rates of base substitutions through comparative studies of nucleotide sequences. J Mol Evol 16, 111-120.

Logan, N. A., De Clerck, E., Lebbe, L., Verhelst, A., Goris, J., Forsyth, G., Rodriguez-Diaz, M., Heyndrickx, M. \& De Vos, P. (2004). Paenibacillus cineris sp. nov. and Paenibacillus cookii sp. nov., from Antarctic volcanic soils and a gelatin-processing plant. Int J Syst Evol Microbiol 54, 1071-1076.

Marshall, B. J. \& Ohye, D. F. (1966). Bacillus macquariensis n.sp., a psychrotrophic bacterium from sub-antarctic soil. J Gen Microbiol 44, 41-46.

Meehan, C., Bjourson, A. J. \& McMullan, G. (2001). Paenibacillus azoreducens sp. nov., a synthetic azo dye decolorizing bacterium from industrial wastewater. Int J Syst Evol Microbiol 51, 1681-1685.

Nazina, T. N., Tourova, T. P., Poltaraus, A. B. \& 8 other authors (2001). Taxonomic study of aerobic thermophilic bacilli: descriptions of Geobacillus subterraneus gen. nov., sp. nov. and Geobacillus uzenensis sp. nov. from petroleum reservoirs and transfer of Bacillus stearothermophilus, Bacillus thermocatenulatus, Bacillus thermoleovorans, Bacillus kaustophilus, Bacillus thermoglucosidasius and Bacillus thermodenitrificans to Geobacillus as the new combinations $G$. stearothermophilus, G. thermocatenulatus, G. thermoleovorans, $G$. kaustophilus, G. thermoglucosidasius and G. thermodenitrificans. Int J Syst Evol Microbiol 51, 433-446.

Niimura, Y., Koh, E., Yanagida, F., Suzuki, K., Komagata, K. \& Kozaki, M. (1990). Amphibacillus xylanus gen. nov., sp. nov., a facultatively anaerobic spore-forming xylan-digesting bacterium which lacks cytochrome, quinone, and catalase. Int J Syst Bacteriol 40, 297-301.

Pikuta, E., Lysenko, A., Chuvilskaya, N., Mendrock, U., Hippe, H., Suzina, N., Nikitin, D., Osipov, G. \& Laurinavichius, K. (2000). Anoxybacillus pushchinensis gen. nov., sp. nov., a novel anaerobic, alkaliphilic, moderately thermophilic bacterium from manure, and description of Anoxybacillus flavithermus comb. nov. Int J Syst Evol Microbiol 50, 2109-2117.

Saitou, N. \& Nei, M. (1987). The neighbor-joining method: a new method for reconstructing phylogenetic trees. Mol Biol Evol 4, 406-425.

Sambrook, J., Fritsch, E. F. \& Maniatis, T. (1989). Molecular Cloning: a Laboratory Manual, 2nd edn. Cold Spring Harbor, NY: Cold Spring Harbor Laboratory.

Schlesner, H., Lawson, P. A., Collins, M. D., Weiss, N., Wehmeyer, U., Völker, H. \& Thomm, M. (2001). Filobacillus milensis gen. nov., sp. nov., a new halophilic spore-forming bacterium with Orn-DGlu-type peptidoglycan. Int J Syst Evol Microbiol 51, 425-431.

Shida, O., Takagi, H., Kadowaki, K. \& Komagata, K. (1996). Proposal for two new genera. Brevibacillus gen. nov. and Aneurinibacillus gen. nov. Int J Syst Bacteriol 46, 939-946.

Shida, O., Takagi, H., Kadowaki, K., Nakamura, L. K. \& Komagata, K. (1997a). Transfer of Bacillus alginolyticus, Bacillus chondroitinus, Bacillus curdlanolyticus, Bacillus glucanolyticus, Bacillus kobensis and Bacillus thiaminolyticus to the genus Paenibacillus and emended description of the genus Paenibacillus. Int J Syst Bacteriol 47, 289-298.

Shida, O., Takagi, H., Kadowaki, K., Nakamura, L. K. \& Komagata, K. (1997b). Emended description of Paenibacillus amylolyticus and description of Paenibacillus illinoisensis sp. nov. and Paenibacillus chibensis sp. nov. Int J Syst Bacteriol 47, 299-306.

Smibert, R. \& Krieg, N. R. (1994). Phenotypic characterization. In Methods for General and Molecular Bacteriology, pp. 607-654. Edited by P. Gerhardt, R. G. E. Murray, W. A. Wood \& N. R. Krieg. Washington, DC: American Society for Microbiology. 
Spring, S., Ludwig, W., Marquez, M. C., Ventosa, A. \& Schleifer, K.-H. (1996). Halobacillus gen. nov., with description of Halobacillus litoralis sp. nov. and Halobacillus truperi sp. nov., and transfer of Sporosarcina halophilia to Halobacillus halophilus comb. nov. Int J Syst Bacteriol 46, 492-496.

Stackebrandt, E. \& Goebel, B. M. (1994). Taxonomic note: a place for DNA-DNA reassociation and $16 \mathrm{~S}$ rRNA sequence analysis in the present species definition in bacteriology. Int J Syst Bacteriol 44, 846-849.

Tcherpakov, M., Ben-Jacob, E. \& Gutnick, D. L. (1999). Paenibacillus dendritiformis sp. nov., proposal for a new pattern-forming species and its localization within a phylogenetic cluster. Int J Syst Bacteriol 49, 239-246.

Thompson, J. D., Higgins, D. G. \& Gibson, T. J. (1994). CLUSTAL W: improving the sensitivity of progressive multiple sequence alignment through sequence weighting, position-specific gap penalties and weight matrix choice. Nucleic Acids Res 22, 4673-4680.

Velázquez, E., De Miguel, T., Poza, M., Rivas, R., Rosselló-Mora, R. \& Villa, T. G. (2004). Paenibacillus favisporus sp. nov., a xylanolytic bacterium isolated from cow faeces. Int J Syst Evol Microbiol 54, 59-64.

Wainø, M., Tindall, B. J., Schumann, P. \& Ingvorsen, K. (1999). Gracilibacillus gen. nov., with description of Gracilibacillus halotolerans gen. nov., sp nov.; transfer of Bacillus dipsosauri to Gracilibacillus dipsosauri comb. nov., and Bacillus salexigens to the genus Salibacillus gen. nov., as Salibacillus salexigens comb. nov. Int J Syst Bacteriol 49, 821-831.

Wayne, L. G., Brenner, D. J., Colwell, R. R. \& 9 other authors (1987). International Committee on Systematic Bacteriology. Report of the ad hoc committee on reconciliation of approaches to bacterial systematics. Int J Syst Bacteriol 37, 463-464.

Wisotzkey, J. D., Jurtshuk, P., Jr, Fox, G. E., Deinhard, G. \& Poralla, K. (1992). Comparative sequence analyses on the $16 \mathrm{~S}$ rRNA (rDNA) of Bacillus acidocaldarius, Bacillus acidoterrestris, and Bacillus cycloheptanicus and proposal for creation of a new genus, Alicyclobacillus gen. nov. Int J Syst Bacteriol 42, 263-269.

Yoon, J.-H., Yim, D. K., Lee, J.-S., Shin, K.-S., Sato, H. H., Lee, S. T., Park, Y. K. \& Park, Y.-H. (1998). Paenibacillus campinasensis sp. nov., a cyclodextrin-producing bacterium isolated in Brazil. Int $J$ Syst Bacteriol 48, 833-837.

Yoon, J.-H., Weiss, N., Lee, K.-C., Lee, I.-S., Kang, K. H. \& Park, Y.-H. (2001). Jeotgalibacillus alimentarius gen. nov., sp. nov., a novel bacterium isolated from jeotgal with L-lysine in the cell wall, and reclassification of Bacillus marinus Rüger 1983 as Marinibacillus marinus gen. nov., comb. nov. Int J Syst Evol Microbiol 51, 2087-2093. 